\title{
Redescription of Marstonia comalensis (Pilsbry \& Ferriss, 1906), a poorly known and possibly threatened freshwater gastropod from the Edwards Plateau region (Texas)
}

\author{
Robert Hershler', Hsiu-Ping Liu \\ I Department of Invertebrate Zoology, Smithsonian Institution, P.O. Box 37012, Washington, D. C. 20013- \\ 7012, USA 2 Department of Biology, Metropolitan State College of Denver, Denver, CO 80217, USA
}

Corresponding author: Robert Hershler (hershlerr@si.edu)

Academic editor: Anatoly Schileyko | Received 2 June 2010 | Accepted 13 January 2011 | Published 26 January 2011

Citation: Hershler R, Liu H-P (2011) Redescription of Marstonia comalensis (Pilsbry \& Ferriss, 1906), a poorly known and possibly threatened freshwater gastropod from the Edwards Plateau region (Texas). ZooKeys 77: 1-16. doi: 10.3897/ zookeys.77.935

\begin{abstract}
Marstonia comalensis, a poorly known nymphophiline gastropod (originally described from Comal Creek, Texas) that has often been confused with Cincinnatia integra, is re-described and the generic placement of this species, which was recently allocated to Marstonia based on unpublished evidence, is confirmed by anatomical study. Marstonia comalensis is a large congener having an ovate-conic, openly umbilicate shell and penis having a short filament and oblique, squarish lobe bearing a narrow gland along its distal edge. It is well differentiated morphologically from congeners having similar shells and penes and is also genetically divergent relative to those congeners that have been sequenced (mtCOI divergence 3.0-8.5\%). A Bayesian analysis of a small COI dataset resolved $M$. comalensis in a poorly supported sub-clade together with $M$. hershleri, $M$. lustrica and $M$. pachyta. The predominantly new records presented herein indicate that $M$. comalensis was historically distributed in the upper portions of the Brazos, Colorado, Guadalupe and Nueces River basins, south-central Texas. The species has been live collected at only 12 localities and only two of these have been re-visited since 1993. These data suggest that the conservation status of this snail, which has a critically imperiled (G1) NatureServe ranking and was recently proposed for federal listing, needs to be re-assessed.
\end{abstract}

\section{Keywords}

Marstonia, Hydrobiidae, Gastropoda, United States, Texas, freshwater, taxonomy, conservation

Copyright R. Hershler, H.-P. Liu. This is an open access article distributed under the terms of the Creative Commons Attribution License, which permits unrestricted use, distribution, and reproduction in any medium, provided the original author and source are credited. 


\section{Introduction}

The freshwater gastropod genus Marstonia (Hydrobiidae: Nymphophilinae) is composed of 15 small (shell height $<5.0 \mathrm{~mm}$ ), ovate- to elongate-shelled species that are distributed in springs, streams and lakes in eastern North America (Thompson and Hershler 2002, Hershler et al. 2003a, Thompson 2005). Most of these species have extremely narrow geographic ranges and consequently have become a focus of conservation activities; two are federally listed as endangered (USFWS 1994, 2000) and others are variously listed by state wildlife agencies. Marstonia differs from the other eight North American nymphophiline genera in that the (female) oviduct and bursal duct join well in front of (instead of behind) the posterior wall of the pallial cavity (Thompson and Hershler 2002); it has also been resolved as a well supported sub-clade within its subfamily based on mtDNA sequences (Hershler et al. 2003a). Although Marstonia has been reviewed three times since 1978 (Thompson 1978, Hershler 1994, Thompson and Hershler 2002), three of its congeners have been little studied beyond their original descriptions and their anatomy is unknown. Two of these $-M$. olivacea (Pilsbry), M. ozarkensis (Hinkley) — may be extinct (Thompson 1978, NatureServe 2009) and thus will likely remain incertae sedis. The third, M. comalensis (Pilsbry and Ferriss) (originally Amnicola comalensis Pilsbry \& Ferriss), which is extant, is the focus of this paper.

Pilsbry and Ferriss (1906) described A. comalensis based on six shells from Comal Creek and the Guadalupe River near New Braunfels, south-central Texas. They differentiated this species from $A$. limosa (Say) and two nomina (A. cincinnatiensis [Anthony], A. peracuta Pilsbry \& Walker) that are currently recognized as synonyms of Cincinnatia integra (Say) (see Hershler and Thompson 1996) by its much smaller size and noted that it further differed from the latter by its less shouldered whorls. The genus Amnicola was used at that time as "a catch-all for most American amnicoloid species that could not conveniently be placed elsewhere on the basis of their shells" (Thompson 1968: 150). Amnicola comalensis was not further treated taxonomically until Taylor (1975) transferred it to Cincinnatia without comment in a bibliographic compilation; this allocation was widely followed in the subsequent literature (e.g., Burch and Tottenham 1980, Turgeon et al. 1998). During the course of a revisionary study of $C$. integra, Hershler and Thompson (1996) examined several alcohol preserved collections of a snail that they identified as $A$. comalensis and noted that it closely resembled species of Marstonia (which were then placed in Pyrgulopsis); A. comalensis was subsequently transferred to Marstonia based on this unpublished work (Thompson and Hershler 2002). Hershler et al. (2003a) recently published a molecular phylogenetic analysis of the North American nymphophilines that included a specimen of M. comalensis from Old Faithful Spring in Real County, Texas (ca. $180 \mathrm{~km}$ from the type locality), which was depicted as nested within the Marstonia clade. This is the only published record for $M$. comalensis subsequent to its original description. 
We redescribe $M$. comalensis herein based on study of a large series of dry shell and alcohol-preserved material, most of which was collected by malacologists J.J. Landye and D.W. Taylor from 1971-1993, and provide anatomical evidence supporting its current generic allocation. The new records detailed in this paper considerably expand the geographic range of $M$. comalensis, which lives in springs and fluvial habitats spread among four river basins in south-central Texas. We also further analyze previously published molecular data (Hershler et al. 2003a) to evaluate the divergence and phylogenetic relationships of $M$. comalensis, whose geographic range is broadly disjunct relative to other members of the genus. The information presented in this paper may assist efforts to protect this poorly known species, which was included in a recent federal listing petition (Rosmarino and Tutchton 2007) based on its critically imperiled (G1) NatureServe (2009) ranking, but found not to warrant listing owing to insufficient information (USFWS 2009).

\section{Materials and methods}

Anatomical study was based on specimens that were relaxed with menthol crystals and fixed in dilute formalin. Types and other material of M. comalensis in the collections of the Academy of Natural Sciences of Philadelphia (ANSP); Florida Museum of Natural History (FMNH); National Museum of Natural History, Smithsonian Institution (USNM); and University of Minnesota Bell Museum of Natural History (UMBM$\mathrm{NH}$ ) were examined during the course of this study.

Variation in the number of cusps on the radular teeth was assessed using the method of Hershler et al. (2007). Other methods of morphological study and descriptive terminology are those used in recent taxonomic investigations of nymphophiline gastropods (Hershler 1998, Hershler et al. 2003b). Shell data were compiled using Systat for Windows 11.00.01 (SSI 2004).

The molecular phylogenetic analysis included single mtCOI sequences from $M$. comalensis, six other species of Marstonia and representatives of six other North American nymphophiline genera. Hydrobia acuta (Draparnaud) was used as the root. Sample information, GenBank accession numbers and publication references for the sequences are in Table 1. Sequence divergences (uncorrected p distance) were calculated using MEGA4 (Tamura et al. 2007). Phylogenetic relationships were inferred using Bayesian inference in MrBayes 3.12 (Ronquist and Huelsenbeck 2003). MrModeltest ( $\mathrm{Ny}-$ lander 2004) selected the Hasegawa-Kishino-Yano model with some sites assumed to be invariable and with variable sites assumed to follow a discrete gamma distribution $(\mathrm{HKY}+\mathrm{I}+\mathrm{G})$, which best fit the data under the Akaike Information Criterion. In the initial Bayesian analysis the burn-in was set at 10\% (10,000 generations) of the chain length (100,000 generations). Three runs were conducted in MrBayes using the $\mathrm{HKY}+\mathrm{I}+\mathrm{G}$ model and the default random tree option to determine when the loglikelihood sum reached a stable value (by plotting the log-likelihood scores of sample 
Table I. Species (specimen codes), locality details, GenBank accession numbers and publication references for mtCOI sequences.

\begin{tabular}{|c|c|c|c|}
\hline Species (code) & Locality & $\begin{array}{l}\text { GenBank } \\
\text { accession } \\
\text { number }\end{array}$ & Reference \\
\hline $\begin{array}{l}\text { Marstonia agarhecta } \\
\text { Thompson }\end{array}$ & Bluff Creek, Pulaski Co., GA & AF520934 & Hershler et al. 2003a \\
\hline Marstonia castor Thompson & Mercer Mill Creek, Worth Co., GA & AF520938 & Hershler et al. 2003a \\
\hline $\begin{array}{l}\text { Marstonia comalensis } \\
\text { (Pilsbry \& Ferriss) }\end{array}$ & Old Faithful Spring, Real Co., TX & AF520933 & Hershler et al. 2003a \\
\hline $\begin{array}{l}\text { Marstonia halcyon } \\
\text { Thompson }\end{array}$ & Ogeechee River, Screven Co., GA & AF520935 & Hershler et al. 2003a \\
\hline $\begin{array}{l}\text { Marstonia hershleri } \\
\text { (Thompson) }\end{array}$ & Coosa River, Elmore Co., AL & AF520946 & Hershler et al. 2003a \\
\hline Marstonia lustrica (Pilsbry) & $\begin{array}{l}\text { Stockbridge Bowl, Berkshire Co., } \\
\text { MA }\end{array}$ & AF520945 & Hershler et al. 2003a \\
\hline $\begin{array}{l}\text { Marstonia pachyta } \\
\text { Thompson }\end{array}$ & $\begin{array}{l}\text { Limestone Creek, Limestone Co., } \\
\text { AL }\end{array}$ & AF520939 & Hershler et al. 2003a \\
\hline Cincinnatia integra (Say) & $\begin{array}{l}\text { Stream north of Fredericksburg, } \\
\text { Gillespie Co., TX }\end{array}$ & AF520948 & Hershler et al. $2003 \mathrm{a}$ \\
\hline $\begin{array}{l}\text { Notogillia wetherby (Dall) } \\
\text { (WW) }\end{array}$ & $\begin{array}{l}\text { Weeki Wachee River, Hernando } \\
\text { Co., FL }\end{array}$ & AF367630 & Wilke et al. 2001 \\
\hline $\begin{array}{l}\text { Notogillia wetherbyi (Dall) } \\
\text { (RS) }\end{array}$ & Rainbow Springs, Marion Co., FL & AF520918 & Hershler et al. $2003 \mathrm{a}$ \\
\hline $\begin{array}{l}\text { Pyrgulopsis bruneauensis } \\
\text { Hershler }\end{array}$ & $\begin{array}{l}\text { Bruneau Hot Springs, Owyhee Co., } \\
\text { ID }\end{array}$ & AF520941 & Hershler et al. 2003a \\
\hline $\begin{array}{l}\text { Rhapinema dacryon } \\
\text { Thompson }\end{array}$ & Chipola River, Jackson Co., FL & AF520932 & Hershler et al. 2003a \\
\hline $\begin{array}{l}\text { Spilochlamys gravis } \\
\text { Thompson }\end{array}$ & Alexander Springs, Lake Co., FL & AF520919 & Hershler et al. $2003 \mathrm{a}$ \\
\hline Stiobia nana Thompson & Coldwater Spring, Calhoun Co., AL & AF520921 & Hershler et al. 2003a \\
\hline $\begin{array}{l}\text { Hydrobia acuta } \\
\text { (Draparnaud) }\end{array}$ & $\begin{array}{l}\text { Lagoon 6, Suffolk, East Anglia, } \\
\text { United Kingdom }\end{array}$ & AF354773 & Liu et al. 2001 \\
\hline
\end{tabular}

Additional locality details are in Hershler et al. (2003a).

points against generation time). The ln likelihoods started around $-4,300$ and quickly converged upon a stable value of about $-3,050$ after 1,000 generations. For the final run, Metropolis-coupled Markov chain Monte Carlo simulations were performed with four chains for 1,000,000 generations and Markov chains were sampled at intervals of 10 generations to obtain 100,000 sample points. The sampled trees with branch lengths were used to generate a $50 \%$ majority rule consensus tree with the first 5000 trees (equal to 50,000 generations) removed to ensure that the chain sampled a stationary portion. 


\title{
Systematic description
}

\author{
Family Hydrobiidae \\ Subfamily Nymphophilinae \\ Genus Marstonia Baker, 1926
}

\section{Marstonia comalensis (Pilsbry \& Ferriss, 1906)}

Figs 1-3

Amnicola comalensis Pilsbry \& Ferriss, 1906: 171, fig. 37 (Comal Creek, near New Braunfels, Comal County, Texas; also from the Guadalupe River about four miles [3.2 km] above New Braunfels). Pilsbry 1910: 98 (corrected measurement of figured specimen [lectotype]). Walker 1918: 133. Baker 1964: 172 (lectotype selection). Hershler \& Thompson 1996: 51.

Cincinnatia comalensis Taylor 1975: 61 (transfer to Cincinnatia, summary of literature citations). Burch \& Tottenham 1980: 110, fig. 190 (from Pilsbry \& Ferris 1906). Turgeon et al. 1998: 72.

Marstonia comalensis Thompson \& Hershler 2002: 270 (transfer to Marstonia). Hershler et al. 2003a: 366, figs. 2, 3 (new record, phylogenetic analysis).

Types: Figured lectotype, ANSP 91323 (Fig. 1A); paralectotypes (from same lot), ANSP 420575.

Referred material: TEXAS. USNM 123757, USNM 134007, Guadalupe River. ANSP 134247, Nueces River. Bell County: UMBMNH uncat., Salado Creek, Salado, old US $81\left(30.944^{\circ} \mathrm{N}, 97.539^{\circ} \mathrm{W}\right), 14 . I V .1972$. Comal County: ANSP 90562, drift of Guadalupe River, $3.2 \mathrm{~km}$ above New Braunfels $\left(29.756^{\circ} \mathrm{N}, 98.138^{\circ} \mathrm{W}\right)$. UMBMNH uncat., Spring Branch, west of Spring Branch $\left(29.891^{\circ} \mathrm{N}, 98.435^{\circ} \mathrm{W}\right)$, 28.III.1963. USNM 473488, New Braunfels (29.702 ${ }^{\circ}$, $\left.98.124^{\circ} \mathrm{W}\right)$. Kerr County: USNM 874910, South Fork Guadalupe River, ca. $56.4 \mathrm{~km}$ northwest of Leakey $\left(29.957^{\circ} \mathrm{N}, 99.456^{\circ} \mathrm{W}\right)$, 30.XII.1979. USNM 874932, spring run adjacent to South Fork of Guadalupe River, ca. $11.2 \mathrm{~km}$ southwest of Hunt $\left(30.005^{\circ} \mathrm{N}, 99.409^{\circ} \mathrm{W}\right), 30 . X I I .1979$. USNM 883412, North Fork Guadalupe River $\left(30.054^{\circ} \mathrm{N}, 99.486^{\circ} \mathrm{W}\right), 26 . I V .1993$. USNM 874923, North Fork of Guadalupe River at Riverbend Ranch crossing at FM $1340\left(30.065^{\circ} \mathrm{N}\right.$, 99.373 $\left.{ }^{\circ} \mathrm{W}\right), 29 . \mathrm{XII} .1979$. USNM 251887 , Japonica $\left(30.064^{\circ} \mathrm{N}, 99.344^{\circ} \mathrm{W}\right)$. Kimble County: UMBMNH uncat., Llano River at FM 385, $25.6 \mathrm{~km}$ northeast of Junction $\left(30.589^{\circ} \mathrm{N}, 99.598^{\circ} \mathrm{W}\right), 12-13 . I V .1972$. Kinney County: UMBMNH uncat., Nueces

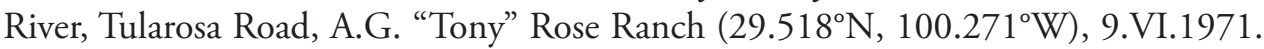
USNM 883413, West Nueces River above crossing on Tularosa Road near Spring Ranch, just below Silver Lake $\left(29.523^{\circ} \mathrm{N}, 100.251^{\circ} \mathrm{W}\right), 25 . I V .1993$. Real County: UMBMNH uncat., USNM 874926, Old Faithful Spring outflow, Hwy 55, 0.8 km north of Camp Wood $\left(29.680^{\circ} \mathrm{N}, 100.015^{\circ} \mathrm{W}\right), 8$. VI.1971, 31.XII.1979. FMNH 283564, FMNH 283565, FMNH 283573, FMNH 287574, Old Faithful Spring, 


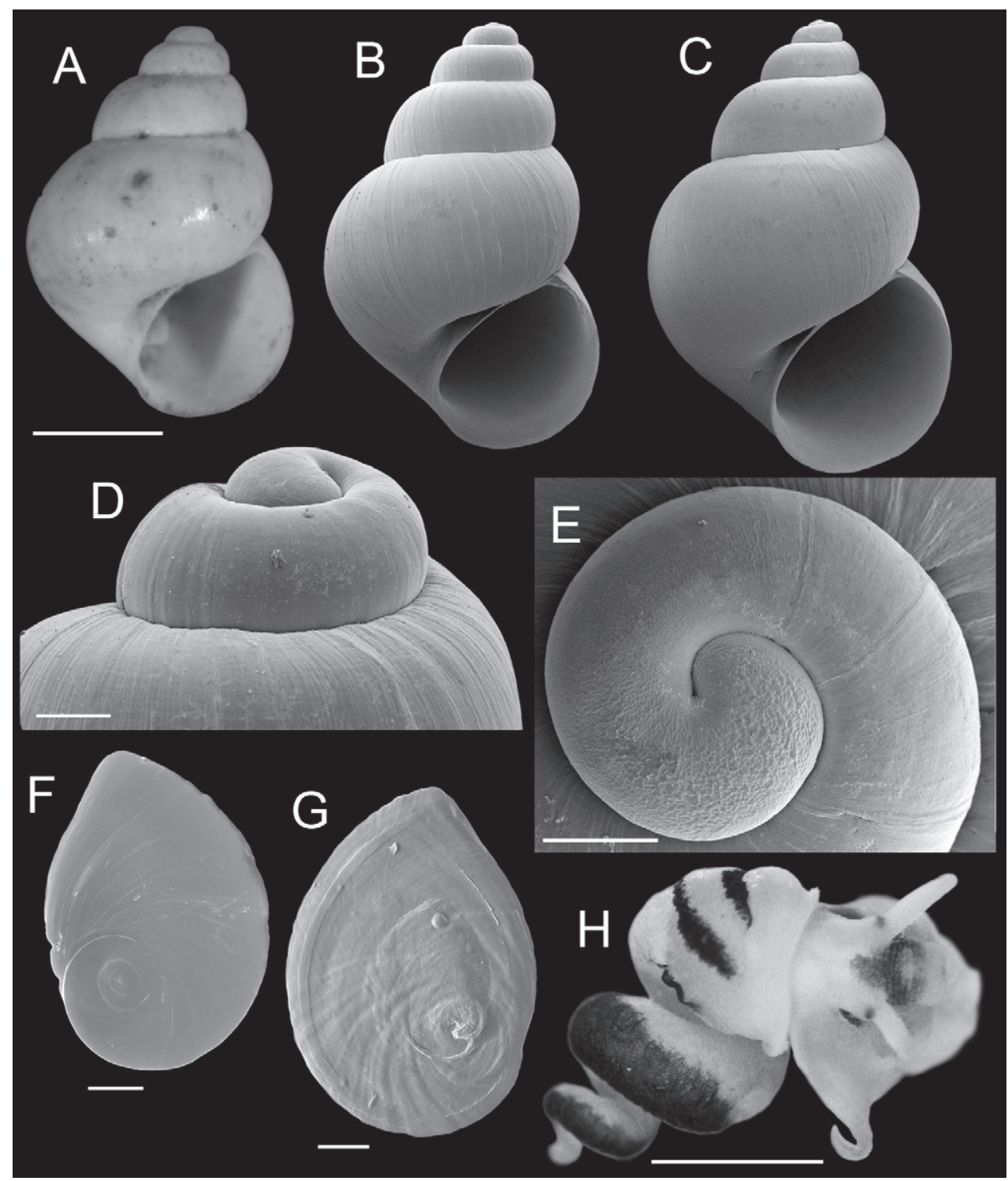

Figure I. Shells, opercula and animal, M. comalensis. A Lectotype, ANSP 91323 B, C Shells, USNM 874932, USNM 874926 D Lateral view of shell apex, USNM 874932 E Protoconch, USNM 874926 F, G Opercula (outer, inner sides), USNM 874926 H Relaxed, alcohol-preserved preserved male (dorsal view), showing distinctive pigment bands on the pallial roof, USNM 874926. Scale bars A-C, H, 1.0 $\mathrm{mm} ; \mathrm{D}, \mathrm{E}, 100 \mu \mathrm{m} ; \mathrm{F}, \mathrm{G}, 200 \mu \mathrm{m}$.

$1.0 \mathrm{~km}$ north of Camp Wood (29.680 $\left.\mathrm{N}, 100.015^{\circ} \mathrm{W}\right), 27 . \mathrm{I} .2001$. USNM 883414, Leakey Springs run at Hwy 337 crossing, ca. $0.48 \mathrm{~km}$ east of Leakey $\left(29.723^{\circ} \mathrm{N}\right.$, 99.757 W), 25.IV.1993. FMNH 283561, Leakey Springs creek, $0.64 \mathrm{~km}$ east of Leakey (29.723 $\left.{ }^{\circ} \mathrm{N}, 99.757^{\circ} \mathrm{W}\right), 26 . I .2001$. Uvalde County: UMBMNH uncat., Nueces River, 


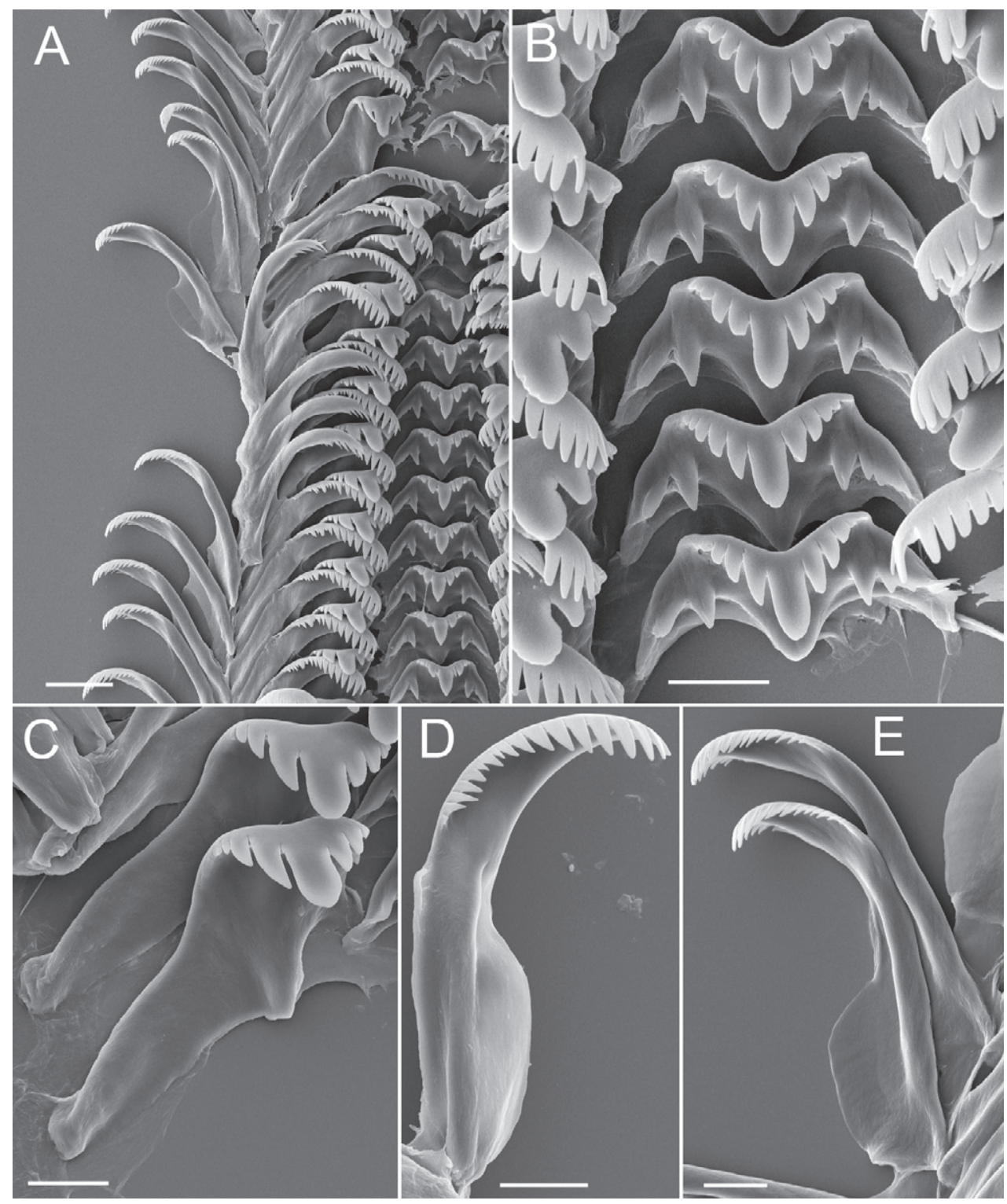

Figure 2. Radula, M. comalensis, USNM 874926. A Portion of radular ribbon B Central teeth C Lateral teeth D Inner marginal tooth E Outer marginal teeth. Scale bars A, $20 \mu \mathrm{m}$; B-E, $10 \mu \mathrm{m}$.

Chalk Bluff, $24 \mathrm{~km}$ northwest of Uvalde $\left(29.359^{\circ} \mathrm{N}, 99.984^{\circ} \mathrm{W}\right), 27 . V .1971$. USNM 883477 , spring at Camp Chalk Bluff, tributary to East Nueces River $\left(29.362^{\circ} \mathrm{N}\right.$, 99.984ํ), 23.IV.1993. USNM 883666, USNM 883421, East Nueces River at 19 Mile Crossing, 1.6-3.2 km south of Hwy 55 and FM $334\left(29.398^{\circ} \mathrm{N}, 100.00^{\circ} \mathrm{W}\right)$, 31.XII.1979, 29.IV.1993. UMBMNH uncat., USNM 883420, East Nueces River, Hwy 55, Lake Nueces County Park (29.619² N, 100.01º W), 1-VI-1971, 29.IV.1993. 


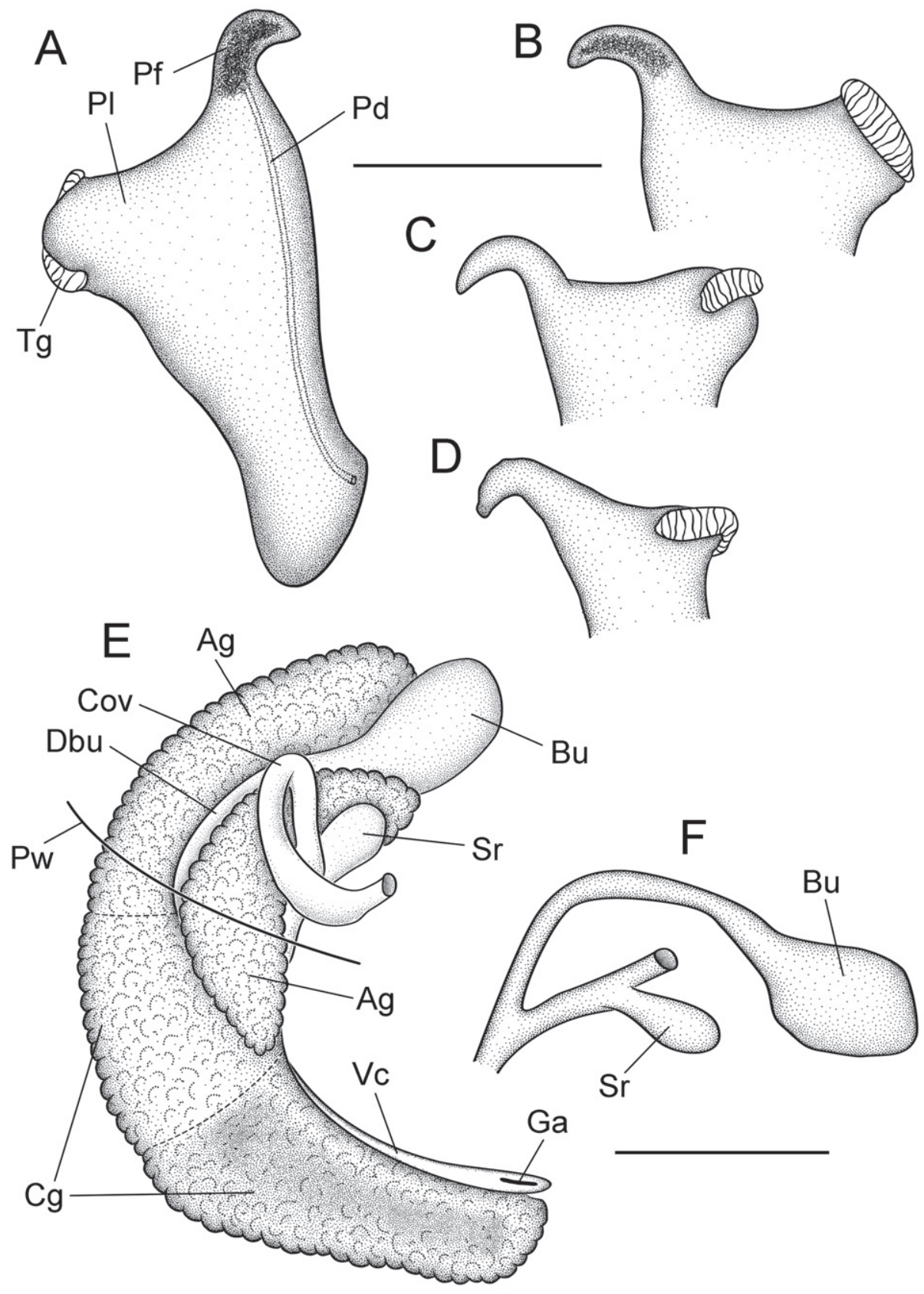

Figure 3. Reproductive anatomy, M. comalensis, USNM 874926. A Penis, dorsal surface B-D Distal portion of penis showing terminal gland variation $\mathbf{E}$ Female glandular oviduct and associated structures (viewed from left side) F Bursa copulatrix and seminal receptacle and their ducts. Scale bars $=500 \mu \mathrm{m}$. $\mathbf{A g}$ albumen gland Bu bursa copulatrix $\mathbf{C g}$ capsule gland $\mathbf{C o v}$ coiled oviduct $\mathbf{D b y}$ bursal duct $\mathbf{G a}$ genital aperture $\mathbf{P f}$ penial filament $\mathbf{P I}$ penial lobe $\mathbf{P w}$ posterior wall of pallial cavity $\mathbf{S r}$ seminal receptacle Vc ventral channel of capsule gland. 


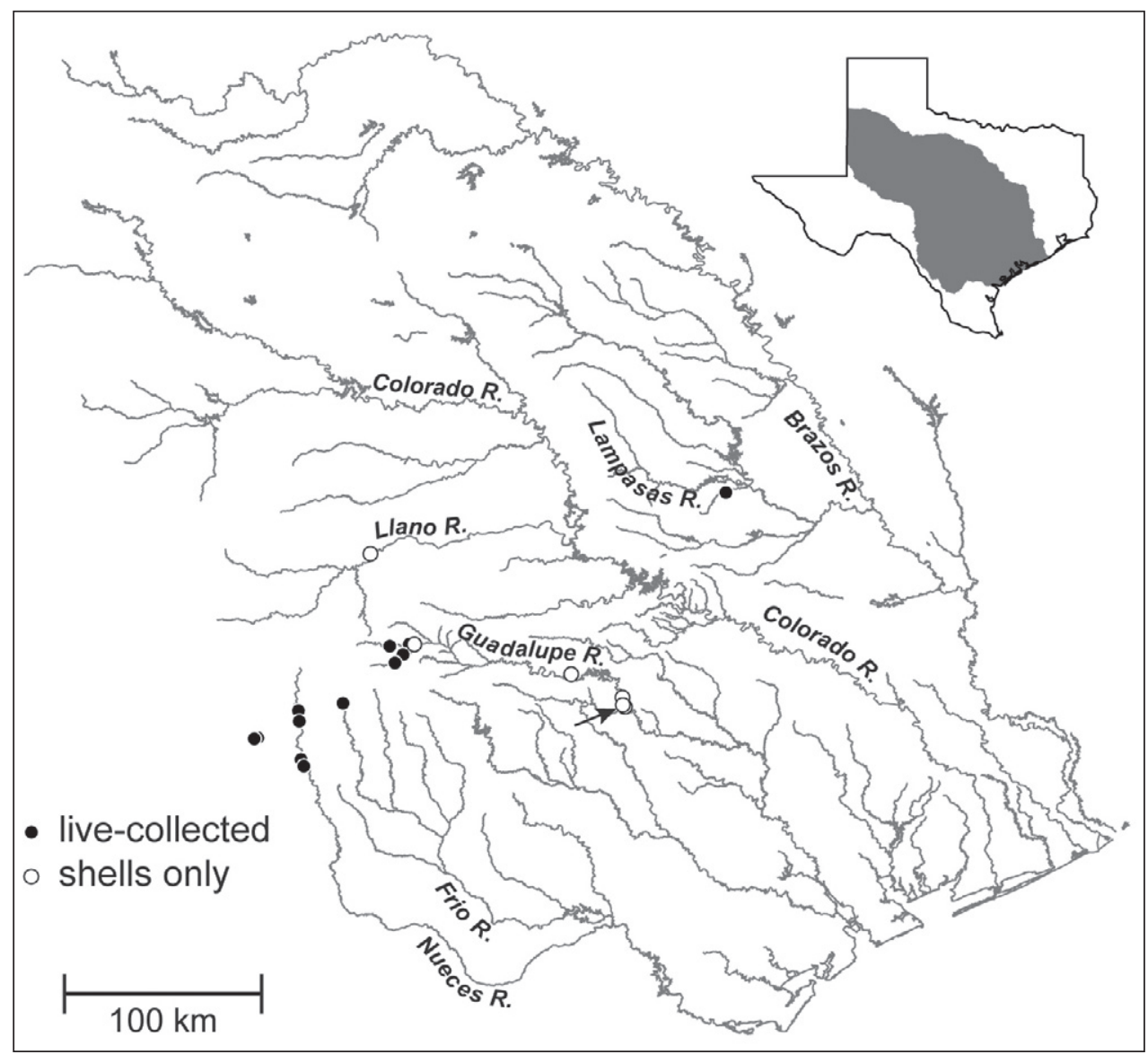

Figure 4. Map showing the distribution of M. comalensis in the Brazos, Colorado, Guadalupe and Nueces River basins, south-central Texas. The arrow indicates the type locality (Comal Creek).

Revised diagnosis: Shell large for genus (maximum height, $4.6 \mathrm{~mm}$ ), ovate-conic, openly umbilicate; penis with short filament and oblique, squarish lobe bearing a single terminal gland along its distal edge. Distinguished from congeners having closely similar shells and penes as follows: from $M$. gaddisorum Thompson by its less convex shell whorls, distinctive pallial roof pigmentation, larger number of cusps on the inner side of the lateral teeth and on the outer marginal teeth, larger penial lobe, narrower terminal gland, and smaller overlap of the bursa copulatrix by the albumen gland; from M. lustrica by its smaller prostate gland, smaller penial lobe, narrower penial filament, straight anterior vas deferens, partly imbedded (in albumen gland) bursal duct, and larger seminal receptacle; and from $M$. ogmorhaphe Thompson by its smaller size, broader shell, smaller prostate gland, straight anterior vas deferens, and smaller bursa copulatrix.

Description: Shell ovate-conic, (Fig. 1A-C); height about 2.6-4.6 mm; whorls 4.5-5.5. Protoconch near planispiral, slightly tilted (Fig. 1D), initial 0.75-1.0 whorl strongly wrinkled (Fig. 1E). Teleoconch whorls weakly convex, often narrowly shoul- 
dered, rarely having subsutural angulation; sculpture of strong collabral growth lines, later whorls having numerous weak spiral striae. Aperture pyriform or ovate. Inner lip complete across parietal wall in larger specimens, usually narrowly adnate, rarely slightly disjunct; usually thin, sometimes slightly thickened apically; columellar shelf absent or very narrow; outer lip thin or slightly thickened, orthocline or prosocline. Umbilicus open but small. Measurements of the lectotype and a live-collected series of shells from the Nueces River basin are in Table 2.

Operculum thin, amber, narrowly ovate, multispiral with eccentric nucleus (Fig. 1F); last 0.25 whorl sometimes frilled on outer side; inner side having well developed rim near outer edge (Fig. 1G); attachment scar border sometimes weakly thickened near nucleus. Radula (Fig. 2A), having about 36 well-formed rows of teeth. Central teeth about $38 \mu \mathrm{m}$ wide, cutting edge convex (Fig. 2B); lateral cusps 3-8; central cusp pointed or hoe-shaped, parallel-sided proximally or tapering throughout; basal cusps 1-3, small; basal tongue U- or V-shaped, about as long as lateral margins. Lateral tooth face rectangular; central cusp pointed or hoe-shaped (Fig. 2C); lateral cusps 2-5 (inner), 3-7 (outer); outer wing broad, flexed, about $140 \%$ length of cutting edge; basal tongue weakly developed. Inner (Fig. 2D) and outer (Fig 2E) marginal teeth both having 14-21 cusps and basally positioned rectangular wing. Radular count data were from USNM 874926.

Cephalic tentacles pale except for black eyespots. Snout brown; distal lips pale; foot pale. Pallial roof having black pigment bands along edges of ctenidium and dorsal edge of genital duct (Fig. $1 \mathrm{H}$ ); visceral coil pale except for black pigment on testis. Ctenidium positioned a little in front of pericardium; ctenidial filaments 24-25 ( $n=5$ ), broadly triangular, lateral surfaces ridged. Osphradium narrow, positioned slightly posterior to middle of ctenidium. Hypobranchial gland large, overlapping rectum and part of genital duct, thickened alongside kidney. Style sac longer than remaining portion of stomach, posterior stomach having small caecal appendix. Testis large (1.75 whorls), composed of compound lobes, broadly overlapping stomach anteriorly. Seminal vesicle opening near anterior edge of testis, composed of a few thickened coils, positioned along ventral side of anterior 33\% of testis. Prostate gland small, pea-shaped, with about $50 \%$ of length in pallial roof. Anterior vas def-

Table 2. Shell parameters for $M$. comalensis.

\begin{tabular}{|c|c|c|c|c|c|c|c|c|c|c|}
\hline & WH & SH & SW & HBW & WBW & AH & AW & SW/SH & HBW/SH & AH/SH \\
\hline \multicolumn{11}{|c|}{ Lectotype, ANSP 91323} \\
\hline & 4.5 & 3.00 & 2.08 & 2.12 & 1.81 & 1.36 & 1.14 & 0.69 & 0.71 & 0.45 \\
\hline \multicolumn{11}{|c|}{ USNM $874926(\mathrm{n}=30)$} \\
\hline Mean & 4.79 & 3.49 & 2.39 & 2.58 & 2.08 & 1.66 & 1.35 & 0.69 & 0.74 & 0.48 \\
\hline S.D. & 0.18 & 0.17 & 0.09 & 0.11 & 0.08 & 0.09 & 0.05 & 0.03 & 0.02 & 0.02 \\
\hline Range & $\begin{array}{l}4.5- \\
5.0\end{array}$ & $\begin{array}{l}3.20- \\
3.87 \\
\end{array}$ & $\begin{array}{l}2.22- \\
2.55 \\
\end{array}$ & \begin{tabular}{|l|}
$2.38-$ \\
2.84 \\
\end{tabular} & $\begin{array}{l}1.93- \\
2.25\end{array}$ & $\begin{array}{l}1.50- \\
1.84 \\
\end{array}$ & $\begin{array}{l}1.26- \\
1.45 \\
\end{array}$ & $0.63-0.74$ & $0.70-0.77$ & $0.43-0.51$ \\
\hline
\end{tabular}

Abbreviations: WH total shell whorls; SH shell height; SW shell width; HBW height of body whorl; WBW width of body whorl; AH aperture height; AW aperture width. 
erens opening from antero-ventral edge of prostate gland, section of duct on columellar muscle straight. Penis large, base rectangular, inner edge without folds; filament short, narrow, tapering, oblique; lobe rather medium-sized, squarish, oblique (Fig. 3A). Terminal gland (Fig. 3A-D) narrow, usually transversely positioned along outer edge of lobe (58/86 specimens examined from three samples), less frequently horizontal (28/86), sometimes borne on short stalk. Penial duct narrow, near outer edge, almost straight. Penial filament having black internal pigment core along most of length. Ovary small ( 0.75 whorl), composed of simple, stalked lobes; slightly overlapping stomach anteriorly. Female glandular oviduct and associated structures shown in Figure 3E-F. Coiled oviduct narrow, vertical. Bursa copulatrix small, ovate, horizontal, about $50 \%$ overlapped by albumen gland. Bursal duct longer than bursa, narrow, opening from distal edge, partly embedded in albumen gland proximally, entirely embedded distally, junction with common duct well in front of posterior wall of pallial cavity. Seminal receptacle small, pouch-like, positioned near ventral edge of albumen gland slightly anterior to bursa copulatrix. Albumen gland largely visceral. Capsule gland composed of two distinct tissue sections. Genital aperture a terminal slit.

Distribution and habitat: Marstonia comalensis is distributed in the upper portions of the Brazos, Colorado, Guadalupe and Nueces River basins, south-central Texas (Fig. 4); almost all of these localities are on the Edwards Plateau. We were unable to confirm a previous report of this species from a drainage canal near Galveston Bay (Cable and Isserhoff 1969). Marstonia comalensis lives in cold water springs near their sources and slack water riverine habitats; it has been most commonly found on mud, aquatic vegetation and dead leaves.

Remarks: The material referred to M. comalensis herein, which includes specimens from the Guadalupe River above the Comal Creek confluence, closely conforms to the types of this species both in size and shell shape (Fig. 1A-C). This snail clearly belongs to Marstonia based on its strongly wrinkled shell protoconch, distally bifurcate penis ornamented with a gland along the edge of the lobe (terminal gland), and connection between the oviduct and bursal duct well in front of the posterior pallial wall (Thompson and Hershler 2002). As noted above, this generic placement is also supported by molecular phylogenetic evidence (Hershler et al. 2003a).

The original collections of $M$. comalensis are worn shells having the appearance of drift material (Fig. 1A). We have not seen any live-collected specimens of this species in the numerous samples that we have examined from the type locality (Comal Springs) and other waters near New Braunfels. The various reports of living M. comalensis from this portion of the Guadalupe River basin (e.g., EHA 1975; Arsuffi 1994; TolleyJordan and Owen 2008) are probably of misidentified C. integra, as evidenced by the illustrations of shells in several of these documents (Lindholm 1979, fig. 4; Cauble 1998, fig. 7). It is possible that $M$. comalensis became extinct at Comal Springs when this water body temporarily dried in 1964 (USFWS 1996); it is also possible that the shells of this species which have been found at this site were washed downflow from extant populations in the headwaters of the Guadalupe River. 
Taylor's (1975) allocation of $A$. comalensis to Cincinnatia appears to have been the result of a misidentification as all of the material in his collection that he referred to this species (per the original labels), including several lots from the type locality, is $C$. integra (RH unpublished). Some of these records were detailed in an unpublished manuscript, "Freshwater molluscs from the Nueces River drainage, Texas" that Taylor circulated in the mid-1970's. Cincinnatia integra, which is widely distributed in Texas (Hershler and Thompson 1996), has been frequently confused with M. comalensis in museum collections despite the obvious differences between their shells that were noted in the original description of the latter (Pilsbry and Ferriss 1906). These two species also well differentiated anatomically (see Hershler and Thompson 1996 for details of the former).

\section{Discussion}

Thompson (1978) speculated that Marstonia is composed of two species lineages that are differentiated by the size and shape of the penial lobe and filament. Marstonia comalensis, which is distributed almost $800 \mathrm{~km}$ distant from its most proximal congener, conforms to the putative lineage characterized by a large, squarish lobe and small, slender filament. This group includes widely ranging $M$. lustrica and species distributed in the Tennessee ( $M$. arga Thompson, M. ogmorhaphe, M. pachyta), Alabama (M. hershleri; see Thompson 1995) and Altamaha (M. gaddisorum; see Thompson 2005) River basins. The molecular phylogenetic relationships of $M$. comalensis were previously delineated by Hershler et al. (2003a), who analyzed a mtCOI dataset using maximum parsimony and maximum likelihood methods. We re-analyzed the relevant portion of these data using a Bayesian algorithm The resulting topology (Fig. 5) is closely similar to those illustrated by Hershler et al. (2003a: figs. 2, 3) and has slightly better resolution. Marstonia is resolved as a well supported (100\% posterior probability) clade. Three congeners living in Georgia coastal drainage, which Thompson (1978) recognized as a distinct lineage based on their elongate penial lobe and robust filament, formed a well supported (95\%) subclade. The other four congeners included in the analysis, which conform to the second putative lineage discussed above, formed a weakly supported subunit, within which $M$. comalensis was positioned as sister to a subclade containing $M$. lustrica and $M$. pachyta. The single sequenced specimen of $M$. comalensis differs from those of the six other congeners that have been similarly analyzed by $3.0-8.5 \%$; it is most similar to $M$. pachyta.

Marstonia comalensis is ranked as critically imperiled (G1) by NatureServe (2009), but has a minimal conservation profile otherwise. Following the negative finding per its proposed listing (USFWS 2009) it was categorized by the USFWS (2010) as "status undefined." It was misidentified as a "mussel" in a ecological sustainability report for the Cibola National Forest Grasslands plan revision (USDAFS 2008) and is not mentioned on the Texas Parks and Wildlife's website (http://www.tpwd.state.tx.us/) or in the State Wildlife Action Plan (Texas Parks and Wildlife 2010). Given that $M$. comalensis has been live-collected at only 12 localities (Fig. 4) and only two of these sites (Leakey Springs, Old Faithful Spring) have been re-visited since 1993, it would 


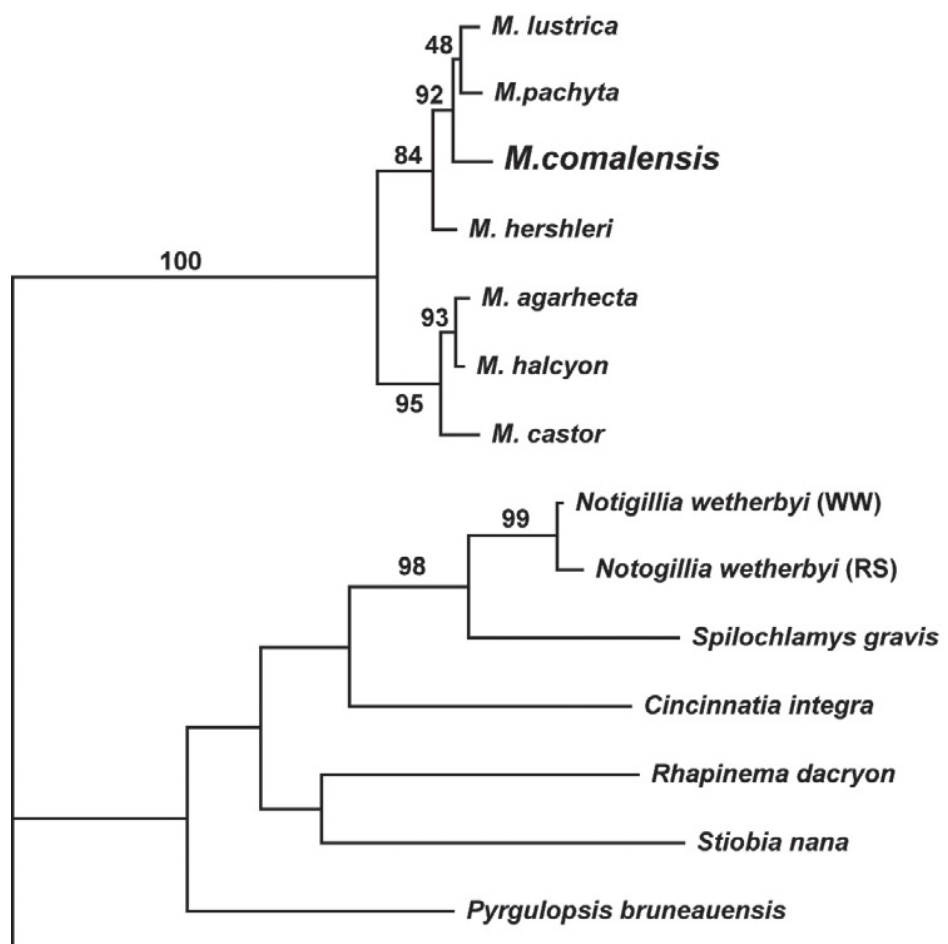

0.1

Hydrobia acuta

Figure 5. Bayesian tree based on the COI dataset. Posterior probabilities for each node within the Marstonia clade are shown for the reader's interest; only those $>95 \%$ are considered significant.

seem prudent to add this species to the list of aquatic biota of the Edwards Plateau region meriting protection (Bowles and Arsuffi 1993) and assess its current conservation status. Depending on the extent of its possible decline since 1993, M. comalensis may merit addition to the IUCN Red List (e.g., if it consists of 10 or fewer extant populations; IUCN 2001) and other conservation watch lists.

\section{Acknowledgements}

We thank Paul Callomon and Amanda Lawless (ANSP), Andrew Simons and Jonathan Slaght (UMBMNH), and Fred Thompson and John Slapcinsky (FLMNH) for loans of specimens under their care. We also thank Peter Diaz and Randy Gibson for providing collections of snails from the type locality area of $M$. comalensis, and Tierra Curry for sharing information regarding this conservation status of this species. Yolanda Villacampa measured shells and prepared scanning electron micrographs, and Karolyn Darrow inked the anatomical drawings. This paper was improved by the comments provided by two anonymous reviewers. 


\section{References}

Arsuffi T (1994) Status of the Comal Springs riffle beetle (Heterelmis comalensis Bosse, Tuff and Brown), Peck's cave amphipod (Stygobromus pecki Holsinger), and the Comal Springs drypoid beetle (Stygoparnus comalensis Barr and Spangler). Contract No. 14-16-0002-90-207. Report to the United States Fish and Wildlife Service, Austin, TX, 26 pp + Appendix 1-5. Baker HB (1964) Type land snails in the Academy of Natural Sciences of Philadelphia. Part III. Limnophile and thalassophile Pulmonata. Part IV. Land and fresh-water Prosobranchia. Proceedings of the Academy of Natural Sciences of Philadelphia 116: 149-193.

Bowles DE, Arsuffi TL (1993) Karst aquatic ecosystems of the Edwards Plateau region of central Texas, USA: a consideration of their importance, threats to their existence, and efforts for their conservation. Aquatic Conservation: Marine and Freshwater Ecosystems 3: 312-329.

Burch JB, Tottenham JL (1980) North American freshwater snails. Species list, ranges and illustrations. Walkerana 1: 81-215.

Cable RM, Isserhoff H (1969) A protandrous haploporid cercaria, probably the larva of Saccocoelioides sogandaresi Lumsden, 1963. Proceedings of the Helminthological Society of Washington 36: 131-135.

Cauble MK (1998) Abundance and distribution of the freshwater snail fauna in Comal SpringsLanda Lake, New Braunfels, Comal Co., TX. M.S. thesis, San Marcos, Texas: Southwest Texas State University.

EHA (Espey, Huston \& Associates, Inc.) (1975) Investigation of flow requirements from Comal and San Marcos Springs to maintain associated aquatic ecosystems Guadalupe River basin. Document No. 7503. Report to the Texas Water Development Board, Austin, TX, i-iii +137 pp.

Hershler R (1994) A review of the North American freshwater snail genus Pyrgulopsis. Smithsonian Contributions to Zoology 554: 1-115.

Hershler R (1998) A systematic review of the hydrobiid snails (Gastropoda: Rissooidea) of the Great Basin, western United States. Part I. Genus Pyrgulopsis. Veliger 41: 1-132.

Hershler R, Thompson FG (1996) Redescription of Paludina integra Say, 1821, type species of genus Cincinnatia (Gastropoda: Hydrobiidae). Journal of Molluscan Studies 62: 33-55.

Hershler R, Liu H-P, Thompson FG (2003a) Phylogenetic relationships of North American nymphophiline gastropods based on mitochondrial DNA sequences. Zoologica Scripta 32: 357-366.

Hershler R, Liu H-P, Frest TJ, Johannes EJ (2007) Extensive diversification of pebblesnails (Lithoglyphidae: Fluminicola) in the upper Sacramento River basin, northwestern United States. Zoological Journal of the Linnean Society of London 149: 371-422.

Hershler R, Frest TJ, Liu H.-P., Johannes EJ (2003b) Rissooidean snails from the Pit River basin, California. Veliger 46: 275-304.

IUCN (International Union for Conservation of Nature) (2001) IUCN Red List Categories and Criteria: Version 3.1. IUCN Species Survival Commission. IUCN, Gland, Switzerland and Cambridge, UK, ii + 30 pp. http://www.iucnredlist.org/documents/redlist_cats_crit_ en.pdf [accessed 3.I.2011] 
Lindholm JJT (1979) The gastropods of the upper San Marcos River and their trematode parasites. M.S. thesis. San Marcos, TX: South Texas State University.

Liu H-P, Hershler R, Thompson FG (2001) Phylogenetic relationships of the Cochliopinae (Rissooidea: Hydrobiidae): an enigmatic group of aquatic gastropods. Molecular Phylogenetics and Evolution 21: 17-25.

NatureServe (2009) NatureServe Explorer: an online encyclopedia of life [web application]. Version 7.1. NatureServe, Arlington, VA. http://www.natureserve.org/explorer [accessed 3.VI.2010]

Nylander JAA (2004) MrModeltest v2. Program distributed by the author. Evolutionary Biology Centre, Uppsala University.

Pilsbry HA (1910) New Amnicolidae of the Panuco River system, Mexico. Nautilus 23: $97-$ 100 , plate IX.

Pilsbry HA, Ferriss JH (1906) Mollusca of the southwestern states. II. Proceedings of the Academy of Natural Sciences of Philadelphia 58: 123-175, plates V-IX.

Ronquist F, Huelsenbeck JP (2003) MRBAYES 3: Bayesian phylogenetic inference under mixed models. Bioinformatics 19: 1572-1574.

Rosmarino NJ, Tutchton JJ (2007) A petition to list all critically imperiled or imperiled species in the southwest United States as threatened or endangered under the Endangered Species Act, 16 U.S.C. $\$ \$ 1531$ et seq. Forest Guardians, Santa Fe, NM, 55 pp. http://www.wildearthguardians.org/Portals/0/support_docs/petition_protection-475-species_6-21-07. pdf [accessed 3.VI.2010]

SSI (Systat Software, Inc.) (2004) Systat ${ }^{\oplus}$ for Windows ${ }^{\oplus}$. Richmond, CA.

Tamura K, Dudley J, Nei M, Kumar, S (2007) MEGA4: Molecular evolutionary genetics analysis (MEGA) software version 4.0. Molecular Biology and Evolution 24: 1596-1599.

Taylor DW (1975) Index and bibliography of late Cenozoic freshwater Mollusca of western North America. University of Michigan Papers on Paleontology 10: 1-384.

Texas Parks and Wildlife (2010) State Wildlife Action Plan (SWAP). http://www.tpwd.state. tx.us/publications/pwdpubs/pwd_pl_w7000_1187a/ [accessed 10.VI.2010]

Thompson FG (1968) The Aquatic Snails of the Family Hydrobiidae of Peninsular Florida; University of Florida Press, Gainesville, 268 pp.

Thompson FG (1978) The hydrobiid snail genus Marstonia. Bulletin of the Florida State Museum Biological Sciences 21: 113-158.

Thompson FG (1995) A new freshwater snail from the Coosa River, Alabama (Gastropoda: Prosobranchia: Hydrobiidae). Proceedings of the Biological Society of Washington 108: 502-507.

Thompson FG (2005) Two new species of hydrobiid snails of the genus Marstonia from Alabama and Georgia. Veliger 47: 175-182.

Thompson FG, Hershler R (2002) Two genera of North American freshwater snails: Marstonia Baker, 1926, resurrected to generic status, and Floridobia, new genus (Prosobranchia: Hydrobiidae: Nymphophilinae). Veliger 45: 269-271.

Tolley-Jordan LR, Owen JM (2008) Habitat influences snail community structure and trematode infection levels in a spring-fed river, Texas, USA. Hydrobiologia 600: 29-40. 
Turgeon DD, Quinn JF, Bogan AS, Coan EV, Hochberg FG, Lyons WG, Mikkelsen PM, Neves RJ, Roper CFE, Rosenberg G, Roth B, Scheltema A, Thompson FG, Vecchione M, Williams JD (1998) Common and scientific names of aquatic invertebrates from the United States and Canada: Mollusks. Second edition. American Fisheries Society Special Publication 26, 526 pp.

USDAFS (United States Department of Agriculture Forest Service) (2008) Ecological sustainability report Kiowa, Rita Blanca, Black Kettle, and McClellan Creek National Grasslands. August 2008 version. Cibola National Forest, Albuquerque, NM, 84pp. http://www.fs.fed. us/r3/cibola/plan-revision/national_grasslands/plandocs/esr_final.pdf [accessed 14.VI.2010]

USFWS (United States Fish and Wildlife Service) (1994) Endangered and threatened wildlife and plants; determination of endangered status for the Royal snail and Anthony's riversnail. Federal Register 59: 17994-17998. http://www.fws.gov/ecos/ajax/docs/federal_register/fr2561.pdf [accessed 4.VI.2010]

USFWS (United States Fish and Wildlife Service) (1996) San Marcos and Comal Springs and associated aquatic ecosystems (revised) recovery plan for San Marcos gambusia (Gambusia georgei), Fountain darter (Etheostoma fonticola), San Marcos salamander (Eurycea nana), Texas wild-rice (Zizania texana), Texas blind salamander (Typhlomolge rathbuni). Prepared for the San Marcos/Comal Recovery Team. Austin, Texas, 121 pp. http://www.fws.gov/ ecos/ajax/docs/recovery_plan/960214.pdf [accessed 15.VI.2010]

USFWS (United States Fish and Wildlife Service) (2000) Endangered and threatened wildlife and plants; endangered status for the Armored snail and Slender campeloma. Federal Register 65: 10033-10039. http://www.fws.gov/ecos/ajax/docs/federal_register/fr3525.pdf [accessed 4.VI.2010]

USFWS (United States Fish and Wildlife Service) (2009) Endangered and threatened wildlife and plants; partial 90-day finding on a petition to list 475 species in the southwestern United States as threatened or endangered with critical habitat; proposed rule. Federal Register 74: 66866-66905. http://www.fws.gov/policy/library/2009/E9-29699.pdf [accessed 3.VI.2010].

USFWS (United States Fish and Wildlife Service) (2010) Species profile. Comal siltsnail (Marstonia comalensis). http://ecos.fws.gov/speciesProfile/profile/speciesProfile.action?spcode=F04C [accessed 14.VI.2010]

Walker B (1918) A synopsis of the classification of the fresh-water Mollusca of North America, north of Mexico, and a catalogue of the more recently described species, with notes. University of Michigan Museum of Zoology Miscellaneous Publications 6: 1-133.

Wilke T, Davis GM, Falniowski A, Giusti F, Bodon M, Szarowska M (2001) Molecular systematic of Hydrobiidae ( Mollusca: Gastropoda: Rissooidea): testing monophyly and phylogenetic relationships. Proceedings of the Academy of Natural Sciences of Philadelphia 151: 1-21. 